\title{
OPTIMIZING THE MICROSTRUCTURE OF LOW-REM ND-FE-B SINTERED MAGNET USING $\mathrm{Dy}_{3} \mathrm{Co}_{0.6} \mathrm{Cu}_{0.4} \mathrm{H}_{\mathrm{X}}$ ADDITION
}

\author{
${ }^{1,2}$ Pavel A. PROKOFEV, ${ }^{1}$ Natalia B. KOLCHUGINA, ${ }^{1}$ Gennadiy S. BURKHANOV, ${ }^{2}$ Alexander A. \\ LUKIN, 1,3Yurii S. KOSHKID'KO, ${ }^{4}$ Katerina SKOTNICOVA, ${ }^{4}$ Tomas CEGAN, ${ }^{3}$ Henryk DRULIS, \\ ${ }^{3}$ Tatyana ROMANOVA, ${ }^{1}$ Nikolay A. DORMIDONTOV \\ ${ }^{1}$ Baikov Institute of Metallurgy and Materials Science, Russian Academy of Sciences, Moscow, Russian \\ Federation, natalik014@yandex.ru,pav3387@yandex.ru \\ 2JSC SPETSMAGNIT", Moscow, Russian Federation, lukinaalukin@rambler.ru \\ 3 Institute of Low Temperature and Structure Research, Polish Academy of Sciences, Wroclaw, Poland, EU \\ HDrulis@int.pan.pl \\ ${ }^{4}$ Vysoka Skola Banska - Technical University of Ostrava, Czech Republic, EU, \\ Katerina.Skotnicova@vsb.cz
}

https://doi.org/10.37904/metal.2019.954

\begin{abstract}
In recent years, the application of various additions (hydrides, oxides, intermetallic compounds, etc.) to powder mixtures for manufacturing Nd-Fe-B magnets shows promise as the method that allows one to increase the hysteretic characteristics of the magnets at the expense of realized grain-boundary diffusion and grainboundary structuring processes. The hysteretic characteristics of sintered $\mathrm{Nd}-\mathrm{Fe}-\mathrm{B}$ magnets are highly sensitive to their microstructure and composition of phases. This paper is focused on the coercivity enhancement of the near-stoichiometric $\mathrm{Nd}_{2} \mathrm{Fe}_{14} \mathrm{~B}$-based magnet by optimizing microstructure, which included processes of grain boundary diffusion and grain boundary structuring via the application of hydrogenated $\mathrm{Dy}_{3} \mathrm{Co}_{0.6} \mathrm{Cu}_{0.4} \mathrm{H}_{\mathrm{x}}$ compound added to the powder mixture. The base alloy having the composition $\mathrm{Nd}-24.0, \mathrm{Pr}-$ 6.5, Dy-0.5, B-1.0, Al-0.2, Fe-balance was prepared by strip-casting technique and subjected to hydrogen decrepitation during heating to $270^{\circ} \mathrm{C}$ in a hydrogen flow at a pressure of $0.1 \mathrm{MPa}$ and subsequent $1 \mathrm{~h}$ holding at this temperature. Dy ${ }_{3} \mathrm{Co}_{0.6} \mathrm{Cu}_{0.4}$ alloy was prepared by arc melting in an argon atmosphere and subjected to homogenizing annealing at $600{ }^{\circ} \mathrm{C}$ for $90 \mathrm{~h}$. The subsequent hydrogenation under the conditions used for the decrepitation of the strip-cast alloy. The phase composition of $\mathrm{Dy}_{3} \mathrm{Co}_{0.6} \mathrm{Cu}_{0.4}$ was studied by X-ray diffraction analysis, DTA and scanning electron microscopy, electron microprobe analysis. Additions of the hydrogenated compound to $\mathrm{Nd}-\mathrm{Fe}-\mathrm{B}$-based sintered magnets allow us to manufacture magnets with $\mathrm{Br}=1.34 \mathrm{~T}$ and $\mathrm{jHc}=$ $1120 \mathrm{kA} / \mathrm{m}$. The microstructure, phase composition and distributions of REM, Co, Cu for the prepared magnets were investigated by SEM/EDX method. Stability of structure-sensitive parameter, namely, the coercive force $\mathrm{jHc}$ of the sintered magnet prepared with $2 \mathrm{wt} \%$ of $\mathrm{Dy}_{3} \mathrm{Co}_{0.6} \mathrm{Cu}_{0.4} \mathrm{H}_{\mathrm{x}}$ addition was studied.
\end{abstract}

Keywords: Grain boundary diffusion, Nd-Fe-B magnets, hydrogenation, microstructure

\section{INTRODUCTION}

Currently, many attempts have been taken to reduce the heavy rare-earth consumption of high-coercivity NdFe-B sintered magnets. Some progress has been achieved in using Dy and/or Tb in various forms, such as oxides, fluorides, hydrides, intermetallic compounds and alloys to realize approaches named grain boundary diffusion (GBD) [1-3] and grain boundary structuring (GBS) [4-8]. The application of binary mixtures with the aforementioned material allows one to improve the structure of boundary phases and grain boundaries of the main magnetic phase and to realize the diffusion of required component of alloy directly through boundaries. It has been demonstrated that through controlling the process time and temperature of GBD processes, the coercivity of the magnet can be greatly enhanced without sacrificing the remanence. 
It was shown in our previous studies that $\mathrm{Tb}$ and Dy hydride additions allow us to increase both the coercive force along with a slight decrease in the remanence [9] and to increase the stability of properties of magnets during low-temperature annealing [10], respectively.

The grain boundary restructuring with rare-earth-rich low-melting compounds added to base low-alloyed NdFe-B-based compositions in the course of technological processing was realized in [4] with $(\mathrm{Pr}, \mathrm{Nd})_{6} \mathrm{Fe}_{13} \mathrm{Cu}$, [5] with $\mathrm{Dy}_{32.5} \mathrm{Fe}_{62} \mathrm{Cu}_{5.5}$, [6] with $\mathrm{Dy}_{69} \mathrm{Ni}_{31}$, [11] with $\mathrm{Dy}_{88} \mathrm{Mn}_{12}$ (wt\% ) composition, [12] with $\mathrm{Pr}_{34.4} \mathrm{Co}_{65.6}$ (wt. \%), and [13] with Dy82.3 $\mathrm{Co}_{17.7}$ (wt\%) that is the low-melting eutectic composition. It was shown that intrinsic coercivity increases obviously with the addition of $\mathrm{D}_{82.3} \mathrm{C}_{017.7}$ and the maximum intrinsic coercivity is obtained when the content of $\mathrm{D}_{82.3} \mathrm{C}_{17.7}$ was $2 \mathrm{wt} \%$. At the same time, the remanence and maximum energy product decrease slightly with the increase of the $\mathrm{D}_{82.3} \mathrm{C}_{17.7}$ content. By adding a small amount of $\mathrm{D}_{82.3} \mathrm{Co}_{17.7}$, the coercivity is improved greatly, and the irreversible loss is decreased sharply. The increase in the Curie temperature of the magnets suggests that $C o$ atoms have entered into the 2:14:1 main phase. Microstructural analysis indicates that a well-developed core-shell structure was formed in the magnets with the addition of Dy82.3 $\mathrm{C}_{17.7 .}$ In all cases in using compositions with a heavy rare-earth metal, it was enriched in the outer region of the $\mathrm{Nd}_{2} \mathrm{Fe}_{14} \mathrm{~B}$ matrix grains during the sintering process, which favored to substitute for $\mathrm{Nd}$ in matrix grains to form the (Nd,Dy) ${ }_{2} \mathrm{Fe}_{14} \mathrm{~B}$ core-shell phase.

This paper is focused on optimizing the microstructure of the near-stoichiometric $\mathrm{Nd}_{2} \mathrm{Fe}_{14} \mathrm{~B}$-based magnet, which included the grain boundary diffusion and grain boundary structuring processes via the application of hydrogenated $\mathrm{Dy}_{3} \mathrm{Co}_{0.6} \mathrm{Cu}_{0.4} \mathrm{H}_{\mathrm{x}}$ composition added to powder mixture.

\section{EXPERIMENTAL}

The $\mathrm{Dy}_{3}\left(\mathrm{Co}_{1-\mathrm{x}} \mathrm{Cu}_{\mathrm{x}}\right)$ alloy with $\mathrm{x}=0.4$ was prepared by arc melting of starting components (distilled Dy-99.9 at\%, electrolytic $\mathrm{Co}$ (K-1 grade), and oxygen-free copper) in an argon atmosphere using a water-cold copper bottom and a nonconsumable tungsten electrode. The ingot was subjected to homogenizing annealing at $600^{\circ} \mathrm{C}$ for $90 \mathrm{~h}$. The ingot was subjected to hydrogenation in two regimes; (regime 1) conditions applied for the stripcasting alloy, namely, the heating to $270^{\circ} \mathrm{C}$ in a hydrogen flow at a pressure of $0.1 \mathrm{MPa}$ and subsequent $1 \mathrm{~h}$ holding at this temperature, and (regime 2) heating in hydrogen atmosphere and holding at $700{ }^{\circ} \mathrm{C}$ in a glass Sieverts-type apparatus were used. In the case of heating up $700{ }^{\circ} \mathrm{C}$, the hydrogenation up to the $\mathrm{Dy}_{3} \mathrm{Co}_{0.6} \mathrm{Cu}_{0.4} \mathrm{H}_{\mathrm{x}}$ composition with $\mathrm{x}=8.26$ was realized. We assume that such hydrogen content corresponds to the complete hydrogenation of dysprosium to a dysprosium hydride.

The phase composition of the $\mathrm{Dy}_{3} \mathrm{Co}_{0.6} \mathrm{Cu}_{0.4}$ and $\mathrm{Dy} 3 \mathrm{CoO}_{6} \mathrm{Cu}_{0.4} \mathrm{H}_{\mathrm{x}}$ compositions with $x=8.26$ was studied by X-ray diffraction (XRD) analysis using an Ultima IV (Rigaku», Japan) diffractometer equipped with a "D/teX" detector, CuKa radiation; the scanning step is $0.001^{\circ}$. X-ray diffraction patterns were process and the phase composition of the alloy was determined using PowderCell software. The data on the crystal structure type, lattice parameters, and crystallographic positions of atoms in the Dy-Co, Dy-Cu, and H-Dy system alloys were used to simulate theoretical XRD patterns [14-16]. The differential thermal analysis of the hydrogenated and dehydrogenated $\mathrm{Dy}_{3} \mathrm{Co}_{0.6} \mathrm{Cu}_{0.4} \mathrm{H}_{\mathrm{x}}$ composition was carried out in an argon atmosphere at a heating / cooling rate of $30^{\circ} \mathrm{C} / \mathrm{min}$ using a Setaram Setsys -1750 installation.

The mixture of the $\mathrm{Dy}_{3} \mathrm{Co}_{0.6} \mathrm{Cu}_{0.4}$ alloy and hydrogen-decrepitated strip-casting alloy (hydrogenated at $270{ }^{\circ} \mathrm{C}$ for $1 \mathrm{~h}$ ) was subjected to fine milling for $40 \mathrm{~min}$ to an average particle size of $3 \mu \mathrm{m}$ using a vibratory mill and isopropyl alcohol medium. After wet compaction of the pulp in a transverse magnetic field of $1500 \mathrm{kA} / \mathrm{m}$, blanks of magnets were sintered at $T=1080{ }^{\circ} \mathrm{C}$ for $2 \mathrm{~h}$ and subjected to optimum heat treatment at $500{ }^{\circ} \mathrm{C}$ for $2 \mathrm{~h}$. The high-resolution field emission gun-scanning electron microscope QUANTA 450 FEG equipped with an EDX APOLLO X microprobe was used for the investigation of microstructure and chemical composition of magnet sample. The subsequent temperature stepped heat treatments in a temperature range of $400-900{ }^{\circ} \mathrm{C}$ were used. The hysteretic properties were measured using a hysteresisgraph. 


\section{RESULTS AND DISCUSSION}

\subsection{X-ray diffraction analysis}

Figure 1 shows $\mathrm{X}$-ray diffraction pattern of the $\mathrm{Dy}_{3} \mathrm{C}_{0.0} \mathrm{Cu}_{0.4}$ alloy subjected to prolonged annealing in an argon atmosphere. Unmarked reflections (Figure 1) belong to the main $\mathrm{Dy}_{3}(\mathrm{Co}, \mathrm{Cu})$ phase; marked reflections correspond to $\mathrm{Dy}(\mathrm{Cu}, \mathrm{Co})$ phase based on $\mathrm{DyCu}[14,15]$. The analysis of crystal structures of the found compounds and construction of theoretical XRD patterns for the simulated structures allowed us to determine variations of lattice parameters of phases alloyed with $\mathrm{Co}$ for $\mathrm{Dy}\left(\mathrm{Cu}_{1-\mathrm{y}} \mathrm{Co}_{\mathrm{y}}\right)$ and with $\mathrm{Cu}$ for $\mathrm{Dy}_{3}\left(\mathrm{Co}_{1-\mathrm{x}} \mathrm{Cu}_{\mathrm{x}}\right)$ (see Table 1).

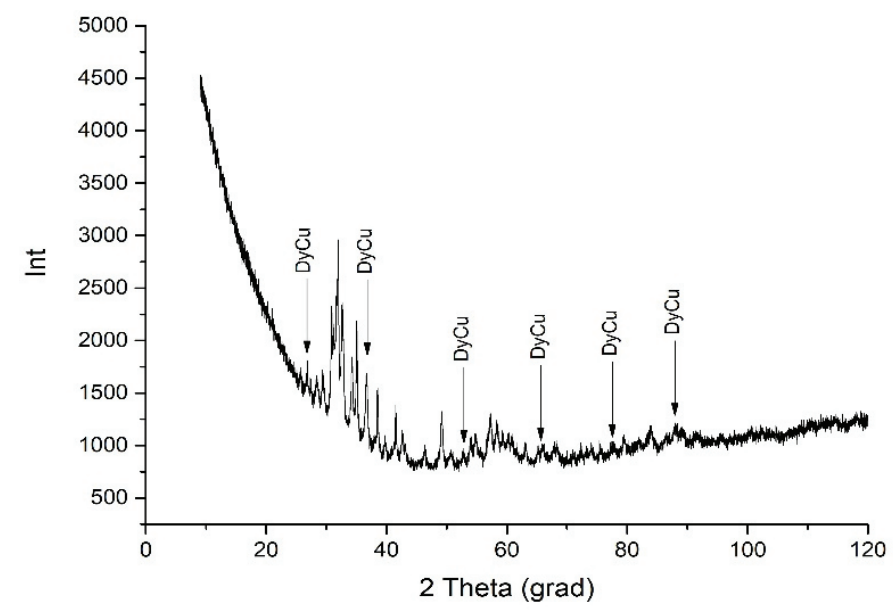

Figure $1 \mathrm{X}$-ray diffraction pattern of the $\mathrm{Dy}_{3}(\mathrm{Co}, \mathrm{Cu})$ alloy

Table 1 Crystallographic parameters of the phases in the $\mathrm{Dy}_{3}(\mathrm{Co}, \mathrm{Cu})$ alloy

\begin{tabular}{|c|l|c|c|c|c|c|c|}
\hline № & \multicolumn{1}{|c|}{ Compound } & Space group & $\boldsymbol{C}$ & $\boldsymbol{a}(\mathrm{nm})$ & $\boldsymbol{b}(\mathrm{nm})$ & $\boldsymbol{c}(\mathrm{nm})$ & References \\
\hline 1 & $\mathrm{Dy}_{3} \mathrm{Co}$ & $\mathrm{Pnma}$ & $\mathrm{Fe}_{3} \mathrm{C}$ & 0.6965 & 0.9341 & 0.6233 & {$[14]$} \\
\hline 2 & $\mathrm{Dy}_{3}\left(\mathrm{Co}_{1-\mathrm{x}} \mathrm{Cu}_{\mathrm{x}}\right)$ & $\mathrm{Pnma}$ & $\mathrm{Fe}_{3} \mathrm{C}$ & 0.69331 & 0.93847 & 6.2564 & This work \\
\hline 5 & $\mathrm{DyCu}$ & $\mathrm{Pm} \overline{3 m}$ & $\mathrm{CsCl}$ & 0.3461 & 0.3461 & 0.3461 & {$[15]$} \\
\hline 6 & $\mathrm{Dy}\left(\mathrm{Cu}_{1-\mathrm{y}} \mathrm{Co}_{\mathrm{y}}\right)$ & $\mathrm{Pm} 3 \mathrm{~m}$ & $\mathrm{CsCl}$ & 0.34522 & 0.34522 & 0.34522 & This work \\
\hline
\end{tabular}

As is seen, the alloying of the binary compounds with Co and Cu does not change the crystal structure type of the binary compounds. The phases present in the alloy are alloyed modifications of the binary compounds in accordance with their phase diagrams $[14,15]$.

As is seen, the substitution of $\mathrm{Cu}$ for Co changes the lattice parameters: the lattice parameters $b$ and $c$ increase because the radius of $\mathrm{Cu}$ atoms $(0.128 \mathrm{~nm})$ is higher than that of Co atoms $(0.125 \mathrm{~nm})$. However, the decrease of the lattice parameter a takes place. This is likely to be due to the fact that copper atoms substitute for cobalt atoms only in certain positions. Similarly to $[17,18]$, the presence of a compound based on $\mathrm{Dy}_{12} \mathrm{Co}_{7}$ is possible.

We assume that the solidification of the alloy occurs via the primary formation of $\mathrm{Dy}_{3} \mathrm{Co}$-based phase by peritectic reaction; the DyCu-based compound is the secondary phase. According to the Co-Dy phase diagram, the solidification path may include the formation of the $\mathrm{Dy}_{12} \mathrm{C}_{07}$-based compound by peritectic reaction.

\subsection{Interaction of $\mathrm{Dy}_{3}(\mathrm{Co}, \mathrm{Cu})$ alloy with hydrogen}

Saturation of the alloy $\mathrm{Dy}_{3} \mathrm{Co}_{0.6} \mathrm{Cu}_{0.4}$ with hydrogen led to the embrittlement of the alloy, i.e., to obtaining the powder material suitable for the further introduction of the composition into the $\mathrm{Nd}-\mathrm{Fe}-\mathrm{B}$ magnetic alloy powder 
during cooperative milling. Figure 2(a) shows X-ray diffraction analysis of the alloy $\mathrm{Dy}_{3} \mathrm{Co}_{0.6} \mathrm{Cu}_{0.4}$ subjected to hydrogenation.
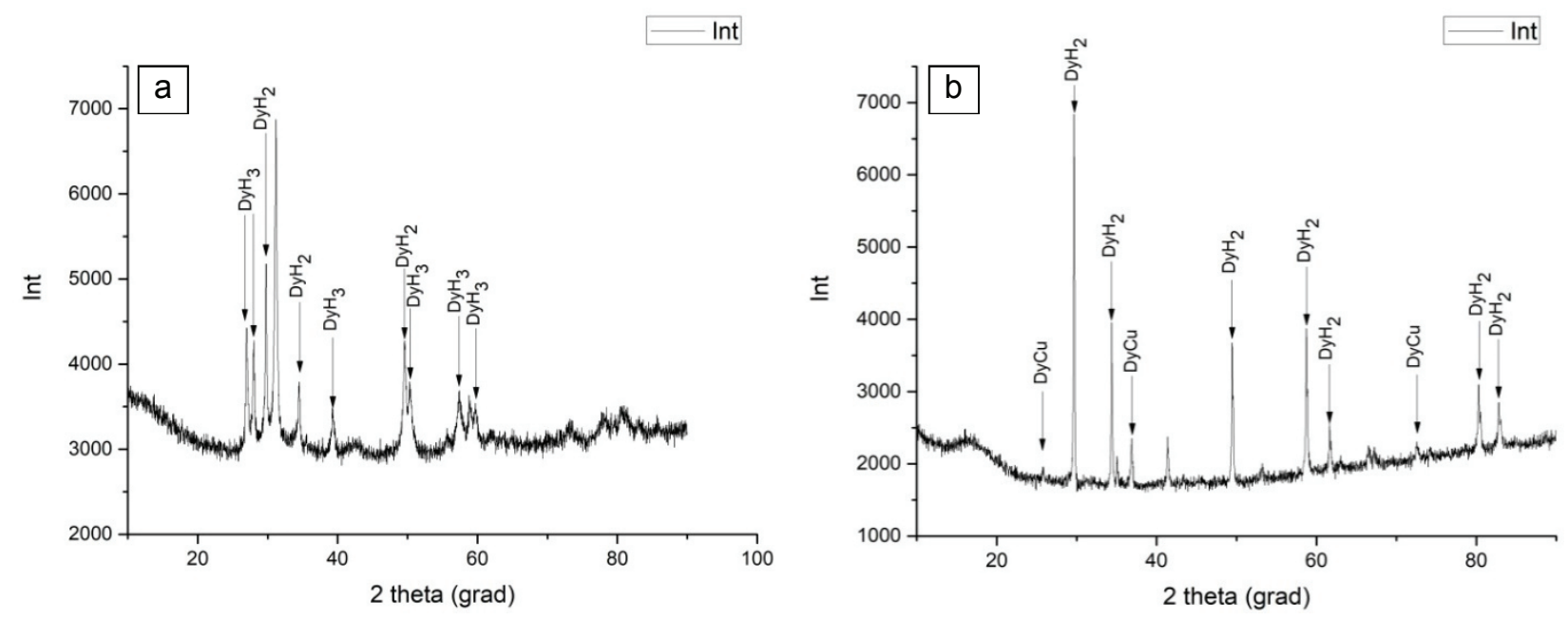

Figure 2 X-ray diffraction pattern of the $\mathrm{Dy}_{3}(\mathrm{Co}, \mathrm{Cu})$ alloy after saturation with hydrogen (a) and after thermal desaturation process (DTA) (b)

The hydrogenated composition contains $\mathrm{DyH}_{2}$ [19] and $\mathrm{DyH}_{3}$ [20]. Unmarked reflections in Figure 2(a) correspond to $\mathrm{Dy}_{3}(\mathrm{Co}, \mathrm{Cu})$ phase. Small quantities of $\mathrm{Dy}_{3}(\mathrm{Co}, \mathrm{Cu})$ and $\mathrm{Dy}(\mathrm{Cu}, \mathrm{Co})$ phases didn't interact with hydrogen. Also, is possible the presence of a thin mechanical mixture of $\mathrm{Cu}$ and $\mathrm{Co}$.

Figure 2(b) shows $\mathrm{X}$-ray diffraction analysis of the alloy $\mathrm{Dy}_{3} \mathrm{Co}_{0.6} \mathrm{Cu}_{0.4} \mathrm{H}_{\mathrm{x}}$ subjected to thermal dehydrogenation (upon heating during DTA). Sample was heated up to $700^{\circ} \mathrm{C}$ (Figure 3). After heating, we observed presence of $\mathrm{DyH}_{2}$ and small quantities of $\mathrm{Dy}_{3}(\mathrm{Co}, \mathrm{Cu})$ and $\mathrm{Dy}(\mathrm{Cu}, \mathrm{Co})$ phases; $\mathrm{DyH}_{3}$ is absent. Also, the presence of a thin mechanical mixture of $\mathrm{Cu}$ and $\mathrm{Co}$ is possible.

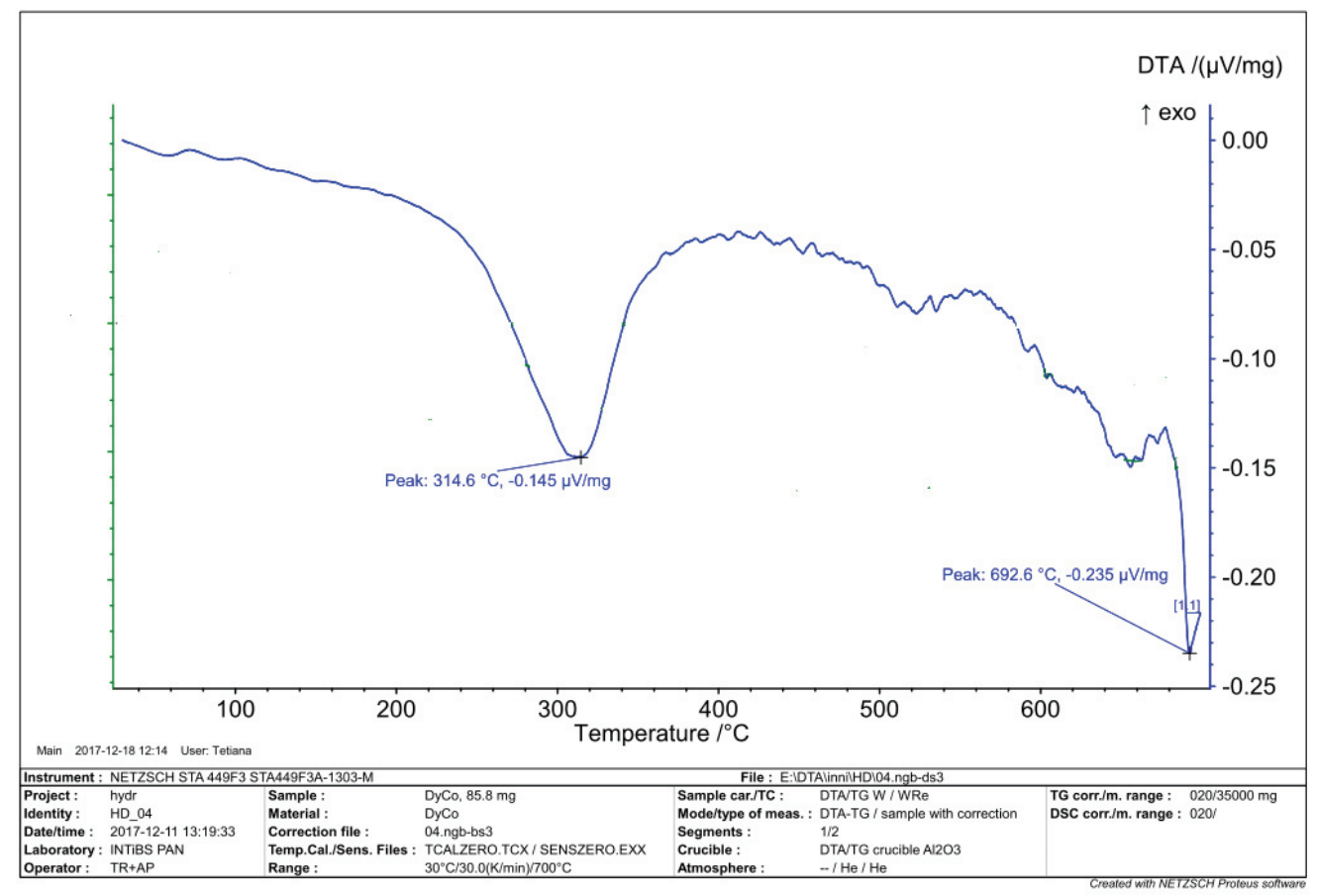

Figure 3 DTA curve of $\mathrm{Dy}_{3}(\mathrm{Co}, \mathrm{Cu}) \mathrm{H}_{8.26}$ sample 
According to the DTA data (Figure 3), the decomposition of $\mathrm{DyH}_{3}$ begins at temperature $\sim 314{ }^{\circ} \mathrm{C}$, which confirmed by literature data [16]. Between $\sim 314{ }^{\circ} \mathrm{C}$ and $\sim 690{ }^{\circ} \mathrm{C}$ there aren't any reactions. At temperature above $\sim 690^{\circ} \mathrm{C}$, in accordance with the $\mathrm{Dy}-\mathrm{H}$ [16] diagram, the solid solution of hydrogen in dysprosium decomposes to form dysprosium. However, the thermal effects at temperatures above $600{ }^{\circ} \mathrm{C}$ can correspond to melting of one the metallic components of the alloy, nevertheless accompanying to the significant weight loss.

The formation of Dy-hydride indicates the possibility of the composition to be used as additions in manufacturing sintered Nd-Fe-B magnets.

\subsection{Microstructure and electron microprobe analysis of sintered NdFeB-based magnet}

In accordance with the microprobe analysis data showed in Table 2, the microstructure (Figure 4) is characterized by the presence of four structural components with different chemical composition (structural components were marked).

Table 2 Chemical analysis of Nd-Fe-B sintered magnet prepared from the powder mixture with 2 wt\% of $\mathrm{Dy}_{3} \mathrm{Co}_{0.6} \mathrm{Cu}_{0.4} \mathrm{H}_{\mathrm{x}}$ compound (in at\%)

\begin{tabular}{|l|c|c|c|c|c|c|c|c|c|}
\hline \multicolumn{1}{|c|}{ Element/phase } & $\mathrm{O}_{\mathrm{K}}$ & $\mathrm{Dy}$ & $\mathbf{A} \mathbf{l}_{\mathrm{K}}$ & $\mathrm{Nb}_{\mathrm{L}}$ & $\mathrm{Pr}_{\mathrm{L}}$ & $\mathbf{N d}_{\mathrm{L}}$ & $\mathrm{Fe}_{\mathrm{K}}$ & $\mathrm{Co}_{\mathrm{K}}$ & $\mathrm{Cu}_{\mathrm{K}}$ \\
\hline Phase_1 & 6.6 & 0.9 & 0.5 & 0.2 & 2.9 & 9.7 & 77.6 & 1.1 & 0.5 \\
\hline Phase_2_1 & 15.7 & 1.1 & 0.5 & 0.3 & 8.9 & 25.6 & 32.7 & 1.1 & 14.1 \\
\hline Phase_2_2 & 6.0 & 6.1 & 0.0 & 1.2 & 11.2 & 29.4 & 44.1 & 1.1 & 1.0 \\
\hline Phase_2_3 & 8.2 & 0.8 & 1.4 & 0.1 & 11.3 & 22.8 & 47.1 & 2.7 & 5.6 \\
\hline Phase_2_4 & 6.8 & 2.9 & 0.9 & 0.2 & 17.8 & 40.6 & 21.1 & 3.7 & 6.1 \\
\hline Phase_3_1 & 47.7 & 0.9 & 0.2 & 0.2 & 7.4 & 22.3 & 20.2 & 0.5 & 0.6 \\
\hline Phase_3_2 & 67.0 & 1.3 & 0.0 & 0.1 & 7.2 & 20.9 & 2.9 & 0.3 & 0.4 \\
\hline Phase_3_3 & 64.9 & 1.4 & 0.0 & 0.2 & 7.7 & 21.8 & 3.7 & 0.3 & 0.2 \\
\hline Phase_4_1 & 14.7 & 0.4 & 0.1 & 40.7 & 0.5 & 1.5 & 41.7 & 0.3 & 0.2 \\
\hline
\end{tabular}
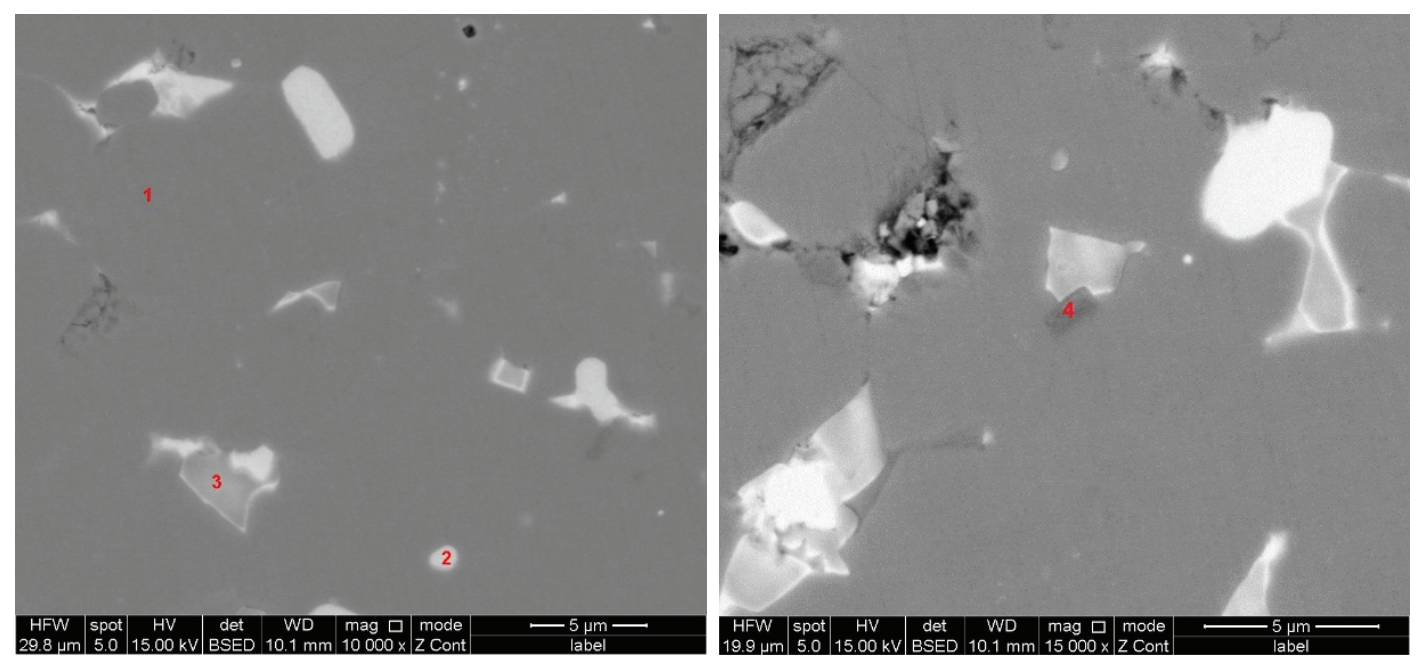

Figure 4 The microstructure of Nd-Fe-B sintered magnet prepared from the powder mixture with 2 wt\% Dy ${ }_{3} \mathrm{Co}_{0.6} \mathrm{Cu}_{0.4} \mathrm{H}_{\mathrm{x}}$; (marked phases correspond to those in Table 2)

The chemical composition of phase 1 (the average values from three analysis) is close to the stoichiometry of $(\mathrm{Nd}, \mathrm{R})_{2} \mathrm{Fe}_{14} \mathrm{~B}$. The presence of Dy in the matrix alloy doesn't allow us to conclude that the core-shell structure 
was formed, but the presence of cobalt in 2:14:1 grains demonstrates the possibility of micro-alloying through the use of hydrogenated low-melting compounds (lower then the sintering temperature of Nd-Fe-B magnets). The Nd-rich phase (phase 2) is characterized by variable composition. In accordance with the microprobe analysis data, there is a strong difference in the content of $\mathrm{Dy}$ and $\mathrm{Cu}$ in the $\mathrm{Nd}$-rich phases. This may indirectly indicate the partial occurrence of the grain boundary diffusion process. Phase 3 (Figure 4) corresponds to oxide phases. In accordance with the literature data [21-22], phase 3 is an oxide phase based on: $\mathrm{NdO}_{1} \mathrm{Nd}_{2} \mathrm{O}_{3}$, $\mathrm{NdO}_{2}$. The presence of a phase based on Fe-Nb in triple junctions was observed (phase 4, Figure 4). This fact may be related to impurities in matrix alloy.

\subsection{Dependence of the coercive force on temperature $\left(\mathrm{j}_{c}\right)$}

The magnetic properties $\left(\mathrm{H}_{c}\right)$ of the magnets (see Table 3) prepared with the hydrogenated $\mathrm{Dy}_{3} \mathrm{Co}_{0.6} \mathrm{Cu}_{0.4}$ alloy are lower than those in the case of $\mathrm{DyH}_{2}$ [23]. One of the causes is incomplete hydrogenation of alloy and incomplete occurrence of grain boundary diffusion of Dy. This fact was confirmed by X-ray diffraction. The small quantity of $\mathrm{Dy}_{3}(\mathrm{Co}, \mathrm{Cu})$ phase is present in the $\mathrm{Dy}_{3} \mathrm{Co}_{0.6} \mathrm{Cu}_{0.4}$ sample after hydrogenation. However, the value of $B_{r}$ in case of $\mathrm{Dy}_{3} \mathrm{Co}_{0.6} \mathrm{Cu}_{0.4} \mathrm{H}_{\mathrm{x}}$ is higher than that in the case of $\mathrm{DyH}_{2}$, it may be due to difference in the Dy content in chemical composition of 2:14:1 phase. The difference in REM and Cu contents in the Nd-rich phases provides to lower value of $H_{k}$ in case of Nd-Fe-B-based magnets with 2 wt $\%$ Dy ${ }_{3} \mathrm{Co}_{0.6} \mathrm{Cu}_{0.4} \mathrm{H}_{\mathrm{x}}$.

Table 3 Magnetic properties of sintered magnets prepared with 2 wt\% $\mathrm{Dy}_{3} \mathrm{Co}_{0.6} \mathrm{Cu}_{0.4} \mathrm{H}_{\mathrm{x}}($ with $x=\sim 2)$ and subjected to optimum heat treatment at $500{ }^{\circ} \mathrm{C}$ for $2 \mathrm{~h}$

\begin{tabular}{|l|c|c|c|c|}
\hline \multicolumn{1}{|c|}{ Addition / Annealing conditions } & $\boldsymbol{B}_{\boldsymbol{r}}(\mathrm{T})$ & ${ }_{j} \boldsymbol{H}_{\boldsymbol{c}}(\mathrm{kA} / \mathrm{m})$ & $\boldsymbol{H}_{\boldsymbol{k}}(\mathrm{kA} / \mathrm{m})$ & $\boldsymbol{B H}_{\max }\left(\mathrm{kJ} / \mathrm{m}^{3}\right)$ \\
\hline $\mathrm{Dy}_{3} \mathrm{Co}_{0.6} \mathrm{Cu}_{0.4} \mathrm{H}_{\mathrm{x}}$ l optimum & 1.34 & 1120 & 968 & 336 \\
\hline $\mathrm{DyH}_{2}$ / optimum & 1.29 & 1309 & 1262 & 322 \\
\hline
\end{tabular}

Figure 5 shows variations of the coercive force $\left(\mathrm{H}_{c}\right)$ with changing heat treatment $(\mathrm{HT})$ temperature. As seen from the curve, the value of ${ }_{j} \mathrm{H}_{c}$ after $\mathrm{HT}$ in a range of temperatures $475-500^{\circ} \mathrm{C}$ rapidly increases.

We assume the optimum $\mathrm{HT}$ for this type of magnets is in the range of 475 to $500{ }^{\circ} \mathrm{C}$ like in case of magnets considered in [17]. Subsequent HT in this temperature range will lead to increase in the coercive force for magnets with $2 \mathrm{wt} \% \mathrm{Dy}_{3} \mathrm{Co}_{0.6} \mathrm{Cu}_{0.4} \mathrm{H}_{\mathrm{x}}$ after optimum heat treatment $\left(500{ }^{\circ} \mathrm{C}\right)$.

\section{CONCLUSIONS}

The phase composition of the $\mathrm{Dy}_{3} \mathrm{Co}_{0.6} \mathrm{Cu}_{0.4}$ alloy in the initial homogenized and hydrogenated states was studied. The alloy in the homogenized state contained $\mathrm{Dy}_{3}(\mathrm{Co}, \mathrm{Cu})$ and $\mathrm{Dy}(\mathrm{Cu}, \mathrm{Co})$ phases. During hydrogenation of the two-phase alloy, the disproportionation or hydrogenolysis process took place, which, whatever the two-phase composition of initial alloy, resulted in the formation of $\mathrm{DyH}_{2-3}$ hydride and probably fine $(\mathrm{Co}+\mathrm{Cu})$ mixture with small quantities of $\mathrm{Dy}_{3}(\mathrm{Co}, \mathrm{Cu})$ and $\mathrm{Dy}(\mathrm{Cu}, \mathrm{Co})$. The possibility for using $\mathrm{Dy}_{3} \mathrm{Co}_{0.6} \mathrm{Cu}_{0} .4 \mathrm{H}_{\mathrm{x}}$ addition to the powder mixture for manufacturing of sintered permanent magnet was shown.

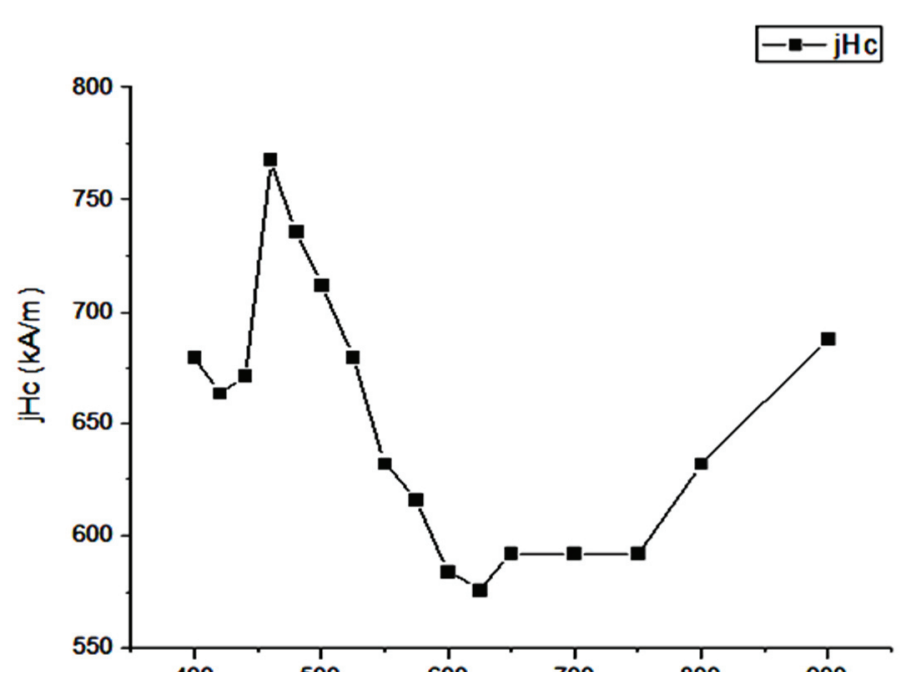

Figure 5 The temperature dependence of the ${ }_{j} \mathrm{H}_{c}$ of $\mathrm{Nd}$ Fe-B-based magnet with 2 wt\% of $\mathrm{Dy}_{3} \mathrm{Co}_{0.6, \mathrm{Cu}_{0.4}}$ 


\section{ACKNOWLEDGEMENTS}

This study was supported by the Ministry of Education and Science of the Russian Federation, agreement no. 14.616.21.0093 (unique identification number RFMEFI61618X0093) and the Ministry of Education, Youth, and Sports of the Czech Republic, project no. LTARF18031.

\section{REFERENCES}

[1] LIU, W. Q., SUN, H., YI, X. F., LIU, X. C., ZHANG, D. T., YUE, M. and ZHANG, J. X. Coercivity enhancement in Nd-Fe-B sintered permanent magnet by Dy nanoparticles doping. Journal of Alloys and Compounds., 2010. vol. 501, pp. 67-69.

[2] SEPEHRI-AMIN, H., LIU, L., OHKUBO, T., YANO, M., SHOJI, T., KATO, A., SCHREFL,T. and HONO, K. Microstructure and temperature dependent of coercivity of hot-deformed Nd-Fe-B magnets diffusion processed with Pr-Cu alloy. Acta Materialia. 2015. vol. 99, pp. 297-306.

[3] KOMURO, M., SATSU, Y. and SUZUKI, H. Increase of coercivity and composition distribution in fluoride-diffused $\mathrm{NdFeB}$ sintered magnets treated by fluoride solutions. IEEE Transactions of Magnets. 2010. vol. 46, pp. 38313833.

[4] $\mathrm{NI}, \mathrm{J} ., \mathrm{MA}, \mathrm{T}$. and YAN, M. Improvement of corrosion resistance in Nd-Fe-B magnets through grain boundaries restructuring. Materials Letters. 2012. vol. 75, pp. 1-3.

[5] LIANG, L., MAN, T., ZHANG, P., JIN, J. and YAN, M. Coercivity enhancement of NdFeB sintered magnets by low melting point Dy ${ }_{32.5} \mathrm{Fe}_{62} \mathrm{Cu}_{5.5}$ alloy modification. Journal of Magnetism and Magnetic Materials. 2014, vol. 355, pp. 131-135.

[6] LIU, X., WANG, X., LIANG, L., ZHANG, P., JIN, J., ZHANG, J., MAN, T. and ANN, M. Rapid coercivity increment of $\mathrm{Nd}-\mathrm{Fe}-\mathrm{B}$ sintered magnets by $\mathrm{D}_{69} \mathrm{Ni}_{31}$ grain boundary restructuring, Journal of Magnetism and Magnetic Materials. 2014. vol. 370, pp. 76-80.

[7] GUO, S., CHEN, R. J., DING, Y., YAN, G. H., LEE, D. and YAN, A. R. Effect of DyHx addition on the magnetic properties and microstructure of $\mathrm{Nd}_{14.1} \mathrm{Co}_{1.34} \mathrm{Cu}_{0.04} \mathrm{Febal}$. B5.84 magnets. Journal of Physics: Conference Series. 2011. vol. 266, pp. 16-19.

[8] KIM, T.-H., LEE, S.-R., KIM, H.-J., LEE, M.-W. and JANG, T.-S. Magnetic and microstructural modification of the Nd-Fe-B sintered magnet by mixed $\mathrm{DyF}_{3} / \mathrm{DyH}_{\mathrm{x}}$ powder doping. Journal of Applied Physics. 2014. vol. 115, no. 17, pp. 17 A763.

[9] LUKIN, A., KOLCHUGINA, N. B., BURKHANOV, G. S., KLYUEVA, N. E. and SKOTNICOVA, K. Role of terbium hydride additions in the formation of microstructure and magnetic properties of sintered Nd-Pr-Dy-Fe-B magnets. Inorganic Materials. Applied Research. 2013. vol. 4, pp. 256-259.

[10] BURKHANOV, G. S., LUKIN, A. A., KOLCHUGINA, N. B., KOSHKID'KO, Yu. S., DORMIDONTOV, A. G., SKOTNICOVÁ, K., ZIVOTSKY, O., ČEGAN, T. and SITNOV, V. V. Effect of low-temperature annealing on the structure and hysteretic properties of Nd-Fe-B magnets prepared with hydride-containing mixtures. In REPM 2014: 23rd International Workshop on Rare-Earth and Future Permanent Magnets and Their Applications. Annapolis, USA, 2014. pp. 367-369.

[11] Li, X., LIU, S., CAO, X., ZHOU, B., CHEN, L., YAN, A. and YAN, G. Coercivity and thermal stability improvement in sintered Nd-Fe-B permanent magnets by intergranular addition of Dy-Mn alloy. Journal of Magnetism and Magnetic Materials. 2016. vol. 407, pp. 247-251.

[12] JIN, C., CHEN, R., YIN, W., TANG, X., WANG, Z., JU, J., LEE, D. and YAN, A. Magnetic properties and phase evolution of Nd-Fe-B magnets with intergranular addition of Pr-Co alloy. Journal of Alloys and Compounds. 2016. vol. 670. pp. 72-77.

[13] ZHANG, X., GUO, S., YAN, C-J., CAI, L., CHEN, R., LEE, D. and YAN, R. Improvement of the thermal stability of sintered Nd-Fe-B magnets by intergranular addition of Dy82.3C017.7. Journal of Applied Physics. 2014, vol. 115, pp. 17 A757.

[14] Binary Alloy Phase Diagram. Ed. by T.B. Massalski, H. Okamoto, P.R. Subramanian, L. Kacprzak, 2nd ed. Materials Park, Ohio: ASM International. 1990. 3589 p. 
[15] MASSALSKI, T.B., OKAMOTO, H., SUBRAMANIAN, P.R., KACPRZAK, L., eds. Binary Alloy Phase Diagrams, Ohio: International Metallographic Society. 1990. 3589 p.

[16] PREDEL, B. Phase Equilibria, Crystallographic and Thermodynamic Data of Binary Alloys' of Landolt-Börnstein Group IV. Physical Chemistry. 1st ed. Berlin: Springer-Verlag 1995. 337 p.

[17] BURKHANOV, G. S., KOLCHUGINA, N. B., KOSHKID KO, Y. S., CWIK, J., SKOTNICOVA, K., CEGAN, T., PROKOF'EV, P. A., DRULIS, H. and HACKEMER, A. Structure and phase composition of $\mathrm{Tb}_{3} \mathrm{Co}_{0.6} \mathrm{Cu}_{0.4}$ alloys for efficient additions to Nd-Fe-B sintered magnets. In METAL 2017 - 26th International Conference on Metallurgy and Materials, Conference Proceedings. 2017, Pages 1775-1781.

[18] PROKOF'EV P. A., KOLCHUGINA N. B., BURKHANOV G. S., LUKIN A. A., KOSHKID'KO Y. S., SKOTNICOVA K., CEGAN T., ZIVOTSKY O. and KURSA M. Phase formation in the Tb-Co-Cu system in a range of $\mathrm{Tb}_{3}(\mathrm{Co}, \mathrm{Cu})$ compound. In METAL 2018: 27th International Conference on Metallurgy and Materials. Ostrava: TANGER. 2018. pp. 1685-1692.

[19] The Materials Project. 2019. [viewed 2019-04-20]. Available from: https://materialsproject.org/materials/mp1191571/.

[20] The Materials Project. 2019. [viewed 2019-04-20]. Available from: URL: https://materialsproject.org/materials/mp24151

[21] KIM, T-H., LEE, S-R., NAMKUMG, S. et al. A study on the Nd-rich phase evolution in the Nd-Fe-B sintered magnet and its mechanism during post-sintering annealing. Journal of Alloys and Compounds. 2012. vol. 537, pp. 261-268.

[22] WANG, S.C. and LI, Y. In situ TEM study of Nd-rich phase in NdFeB magnet. Journal of Magnetism and Magnetic Materials. 2005. vol. 285, pp. 177-182.

[23] BURKHANOV G. S., KOLCHUGINA N. B., LUKIN A. A., KOSHKID`KO Y. S., CWIK J., SKOTNICOVA K. and SITNOV V. V., Structure and Magnetic Properties of Nd-Fe-B Magnets Prepared from $\mathrm{DyH}_{2}-\mathrm{Containing} \mathrm{Powder}$ Mixtures. Inorganic Materials: Applied Research. 2018. vol. 9, pp. 509-516. 